\title{
"Breathing" in Adsorbate-Responsive Metal Tetraphosphonate Hybrid Materials
}

\author{
Rosario M. P. Colodrero, ${ }^{[\mathrm{a}]}$ Aurelio Cabeza, ${ }^{[\mathrm{a}]}$ Pascual Olivera-Pastor, ${ }^{[\mathrm{a}]}$ \\ Antonia Infantes-Molina, ${ }^{[a]}$ Eleni Barouda, ${ }^{[b]}$ Konstantinos D. Demadis, ${ }^{[b]}$ and \\ Miguel A. G. Aranda*[a]
}

\begin{abstract}
The structures of various layered calcium tetraphosphonates $\left(\mathrm{CaH}_{6} \mathrm{DTMP} ; \mathrm{H}_{8} \mathrm{DTMP}=\right.$ hexamethylenediamine tetrakis(methylenephosphonic acid)), have been determined. Starting from $\mathrm{CaH}_{6} \mathrm{DTMP} \cdot 2 \mathrm{H}_{2} \mathrm{O}$, thermal treatment and subsequent exposure to $\mathrm{NH}_{3}$ and/or $\mathrm{H}_{2} \mathrm{O}$ vapors led to four new compounds that showed high storage capacity of guest species between the layers (up to ten $\mathrm{H}_{2} \mathrm{O} / \mathrm{NH}_{3}$ molecules) and a maximum volume increase of $55 \%$. The basic building block for these phosphonates consists of an eight-membered ring chelating
\end{abstract}

$\mathrm{Ca}^{2+}$ through two phoshonate groups, and the organic ligand is located within the layers, which are held together by hydrogen bonds. The structural analysis revealed that the uptake/removal of guest species $\left(\mathrm{H}_{2} \mathrm{O}\right.$ and $\left.\mathrm{NH}_{3}\right)$ induces significant changes in the framework not only by changing the interlayer distances but also through important con-

Keywords: host-guest systems hybrid materials $\cdot$ hydrogen bonds • tetraphosphonates • X X-ray diffraction formational changes of the organic ligand. An anisotropic breathing motion could be quantified by the changes of the unit-cell dimensions and ligand arrangements in four crystalline derivatives. Complete characterization revealed the existence of interconversion reactions between the different phases upon gas uptake and release. The observed behavior represents, to the best of our knowledge, the first example of a breathing-like mechanism in metal phosphonates that possess a 2D topology.

\section{Introduction}

The interdisciplinary field of coordination polymers (or metal-organic frameworks, MOFs) has escalated in recent years owing to several factors, such as significant advances in synthetic methodology, ${ }^{[1]}$ characterization techniques, ${ }^{[2]}$ and, in particular, a plethora of potential applications. ${ }^{[3]}$ It is, therefore, unsurprising that a recent international confer-

[a] R. M. P. Colodrero, Dr. A. Cabeza, Dr. P. Olivera-Pastor, Dr. A. Infantes-Molina, Prof. M. A. G. Aranda Departamento de Química Inorgánica, Universidad de Málaga Campus Teatinos S/N. 29071-Málaga (Spain)

Fax: $(+34) 952132000$

E-mail: g_aranda@uma.es

[b] E. Barouda, Prof. K. D. Demadis

Crystal Engineering, Growth and Design Laboratory

Department of Chemistry, University of Crete

Voutes Campus, Crete, 71003 (Greece)

Fax: $(+30) 2810-545001$

E-mail: demadis@chemistry.uoc.gr

Supporting information for this article is available on the WWW under http://dx.doi.org/10.1002/chem.200900558. ence was exclusively dedicated to MOFs. ${ }^{[4]}$ Whether this field is perceived as a curiosity-driven or applications-driven field, it is broadly accepted that it has significantly taken the level of inorganic/materials chemistry forward. ${ }^{[5]}$ There are now thousands of papers published every year on (functional) coordination polymers (with an emphasis on the porous family members) with potential applications including metal-ion sorption, ${ }^{[6]}$ ion exchange,${ }^{[7]}$ gas absorption and storage $\left(\mathrm{H}_{2},{ }^{[8]} \mathrm{CO}_{2},{ }^{[9]} \mathrm{CH}_{4},{ }^{[10]}\right.$ and others $\left.{ }^{[11]}\right)$, catalysis, ${ }^{[12]}$ fuel cells, ${ }^{[13]}$ surface chemistry, ${ }^{[14]}$ magnetism, ${ }^{[15]}$ and separation. ${ }^{[16]}$ Among the exciting properties of these (porous) coordination polymers, the "breathing effect" has captured the attention of a number of research groups $;^{[17]}$ it can be described as dramatic changes in the dimensions of a stable framework (e.g., unit-cell dimensions) caused by an external stimulus (molecules added and stored within the framework). Volume changes up to $300 \%$ have been reported. ${ }^{[18]}$ Upon closer examination it becomes clear that materials that demonstrate such a dramatic breathing effect are all three dimensional.

Recently, attention has been paid to the use of tetraphosphonates possessing the aminomethylenephosphonate 
$\left(-N-\mathrm{CH}_{2}-\mathrm{PO}_{3} \mathrm{H}_{2}\right)$ group as versatile building blocks to obtain novel hybrid metal derivatives. Depending on the metal and organic groups used, a variety of structures with different topologies have been synthesized, including closely packed three-dimensional ${ }^{[19]}$ and pillared, layered two-dimensional frameworks. ${ }^{[20]}$ In addition, some hybrids with layered structures have the phosphonic groups within the layers. ${ }^{[21]}$ Consequently, this rich structural variability may offer new possibilities for potential applications. Whereas swelling/shrinkage upon ammonia and amine adsorption/desorption is a well-known effect for layered compounds, ${ }^{[22]}$ the high basicity of these guest species usually results in highly disordered solids and prevents further structural characterization of the intercalation compounds.

Herein, we describe the preparation, characterization, structural determination, and breathing effects of a family of novel calcium tetraphosphonates, $\mathrm{CaH}_{6} \mathrm{DTMP}$ $\left(\mathrm{H}_{8} \mathrm{DTMP}=\right.$ hexamethylenediamine tetrakis(methylenephosphonic acid)) with the same calcium/phosphonate molar ratio, but with a different content of the guest molecules (from zero to storage of up to ten $\mathrm{H}_{2} \mathrm{O} / \mathrm{NH}_{3}$ molecules). Host-induced structural changes in the metal phosphonate framework for these compounds, which was deduced from the powder X-ray diffraction (XRD) study, are discussed in detail and $\mathrm{NH}_{3}$ uptake/desorption is also described.

\section{Results and Discussion}

Scheme 1 gives an overview of the relationship/interconversion between the different phases obtained. Note that the highly basic $\mathrm{N}$ atoms remain protonated up to a $\mathrm{pH}$ value of approximately 10 , and for $\mathrm{pH}<4$, each phosphonate group is monodeprotonated. Thus, $\mathrm{H}_{6} \mathrm{DTMP}^{2-}$ $\left(\left[\left(\mathrm{HO}_{3} \mathrm{PCH}_{2}\right)_{2} \mathrm{NH}\left(\mathrm{CH}_{2}\right)_{6} \mathrm{NH}-\right.\right.$ $\left.\left.\left(\mathrm{CH}_{2} \mathrm{PO}_{3} \mathrm{H}\right)_{2}\right]^{2-}\right)$ can be described as a zwitterionic ligand, which is ideal for the construction of divalent metal-phosphonate hybrids based on simple charge-neutralization principles.

The relationship between the phases has been followed by thermodiffractometry.

$\mathrm{CaH}_{6} \mathrm{DTMP} \cdot 2 \mathrm{H}_{2} \mathrm{O}$ (1) was prepared at room temperature by crystallization from a solution with the tetraphosphonic acid and calcium chloride. $\mathrm{CaH}_{6} \mathrm{DTMP}$ (2) was obtained upon dehydration of $\mathbf{1}$ at $250^{\circ} \mathrm{C}$

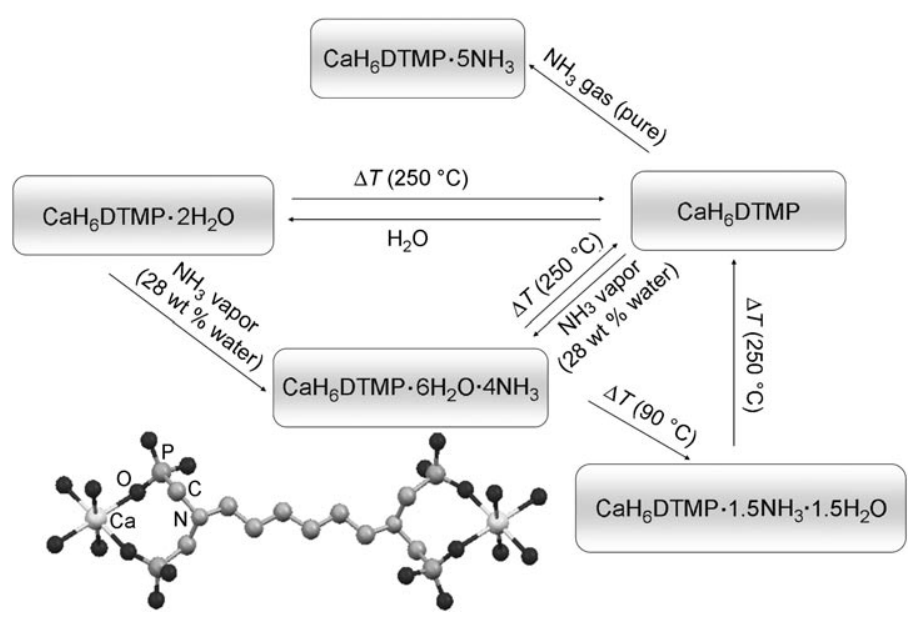

Scheme 1. Interconversions between the reported calcium tetraphosphonate hybrids owing to the incorporation/removal of host molecules. The basic structural unit for this family is also shown.

(Figure 1a). The process is reversed after cooling to room temperature, and rehydration takes place in one day (Figure 1). Both the hydrated and dehydrated phases can be converted into $\mathrm{CaH}_{6} \mathrm{DTMP} \cdot 6 \mathrm{H}_{2} \mathrm{O} \cdot 4 \mathrm{NH}_{3}(3)$ by contact with

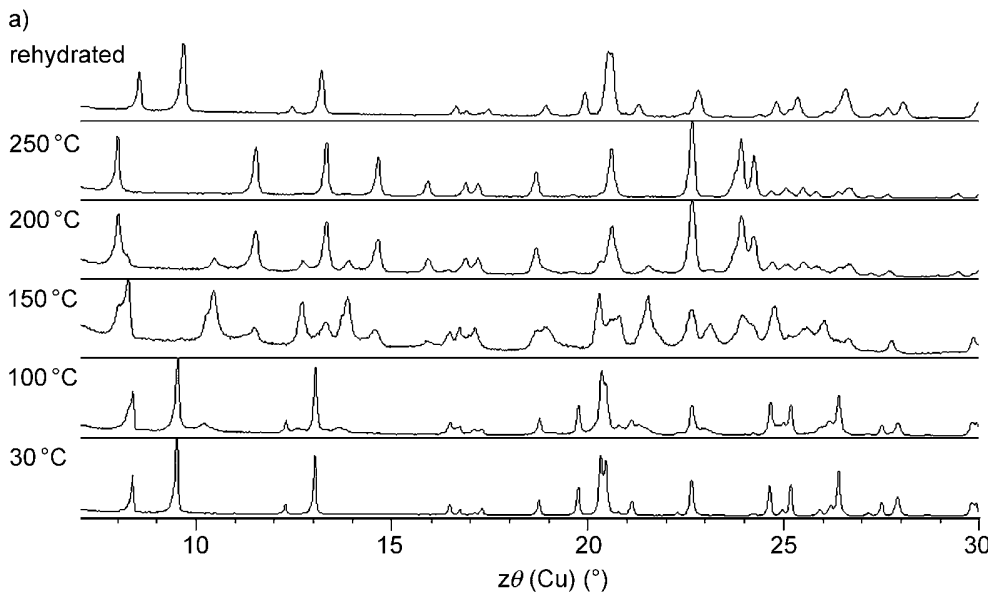

b)

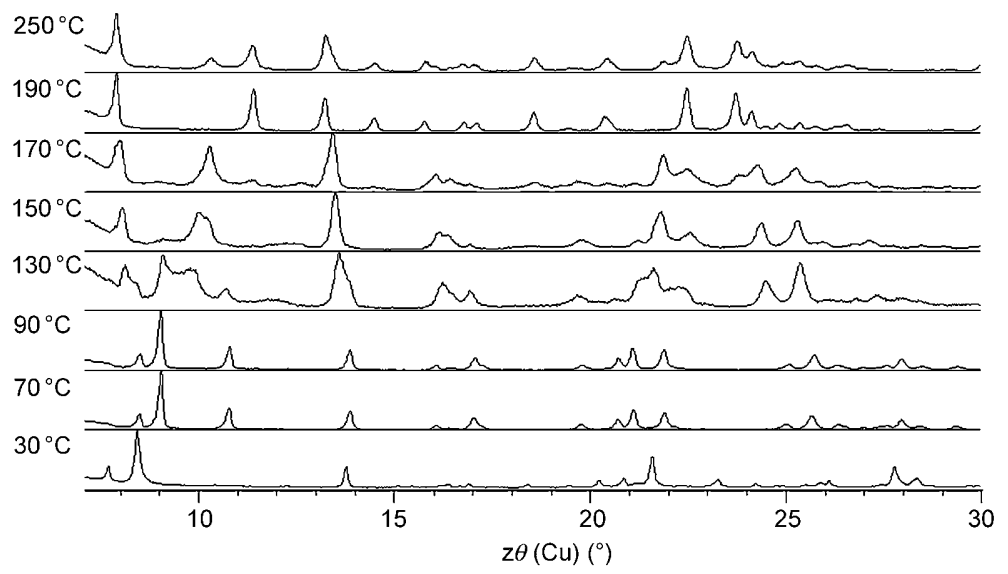

Figure 1. Selected thermodiffraction data for a) $\mathrm{CaH}_{6} \mathrm{DTMP} \cdot 2 \mathrm{H}_{2} \mathrm{O}(\mathbf{1})$ and b) $\mathrm{CaH}_{6} \mathrm{DTMP} \cdot 6 \mathrm{H}_{2} \mathrm{O} \cdot 4 \mathrm{NH}_{3}(\mathbf{3})$ 
the vapors of an aqueous ammonia solution $(28 \mathrm{wt} \%)$. This crystalline solid retained the maximum amount of intercalated guest molecules $\left(10 \mathrm{H}_{2} \mathrm{O} / \mathrm{NH}_{3}\right.$ molecules per formula unit). Thermodiffraction data for $\mathbf{3}$ (Figure $1 \mathrm{~b}$ ) illustrates its transformation under heating at $90{ }^{\circ} \mathrm{C}$ to give a new crystalline phase $\mathrm{CaH}_{6} \mathrm{DTMP} \cdot 1.5 \mathrm{H}_{2} \mathrm{O} \cdot 1.5 \mathrm{NH}_{3}$ (4), which has a lower content of guest species $\left(1.5 \mathrm{H}_{2} \mathrm{O} / 1.5 \mathrm{NH}_{3}\right.$ molecules per formula unit). Compound $\mathbf{2}$ was also obtained by heating 4 at $250^{\circ} \mathrm{C}$. A new poorly crystalline anhydrous phase $\mathrm{CaH}_{6} \mathrm{DTMP} \cdot 5 \mathrm{NH}_{3}$ (5) with only intercalated $\mathrm{NH}_{3}$ was obtained when compound 2 was exposed to pure $\mathrm{NH}_{3}$. Structural characterization of this compound, based on its powder XRD pattern, has been unsuccessful (see the Supporting Information).

The layered structure of $\mathbf{1}$ (Figure 2) is composed of a sixcoordinated $\mathrm{Ca}^{2+}$ center exclusively surrounded by phosphonate oxygen atoms from the $\mathrm{H}_{6} \mathrm{DTMP}^{2-}$ ligand (embedded within the layers) with one crystallographically independent lattice water molecule between the hybrid layers. The basic building block for these phosphonate materials is given in Scheme 1 in which the eight-membered chelate ring and the organic ligand are shown. As shown in Figure 3, the phosphonate groups bridge the calcium polyhedra to give infinite chains along the $a$ axis, which is a common structural feature of all these crystalline hybrids. Note that the layers are only held together through hydrogen bonds and that the organic ligand is located within the layers in contrast with a large number of pillared metal phosphonates in which the phosphonate ligand connects neighboring inorganic layers. ${ }^{[22]}$

The layered structure of $\mathrm{CaH}_{6}$ DTMP compounds significantly differs from that of other alkaline-earth derivatives that have been obtained with the same ligand. $\mathrm{Sr}^{\mathrm{II}}$ and $\mathrm{Ba}^{\mathrm{II}[23]}$ compounds exhibit $1 \mathrm{D}$ structures analogous to those of $\mathrm{Co}^{\mathrm{II}}$ derivatives. ${ }^{[24]}$ However, the $\mathrm{Zn}^{\mathrm{II}}$ hybrid ${ }^{[25]}$ shows a three-dimensional framework, whereas for $\mathrm{Cu}^{\mathrm{II}}$ two different frameworks were obtained: $1 \mathrm{D}^{[23]}$ and $2 \mathrm{D} \cdot{ }^{[20]}$ In the latter case, two sites for $\mathrm{Cu}^{\mathrm{II}}$ were present in the structure, one as part of the organic-inorganic layer and the second one placed between the layers as a hexaaqua dication. On the other hand, $\left[\mathrm{M}^{\mathrm{II}}(\mathrm{tdtmp})\right] \cdot 2 \mathrm{H}_{2} \mathrm{O}$ complexes (TDTMP $=$ $\left(\mathrm{HO}_{3} \mathrm{PCH}_{2}\right)_{2}(\mathrm{H}) \mathrm{N}\left(\mathrm{CH}_{2}\right)_{4} \mathrm{~N}(\mathrm{H})\left(\mathrm{CH}_{2} \mathrm{PO}_{3} \mathrm{H}\right)_{2}, \quad \mathrm{M}=\mathrm{Mg}, \quad \mathrm{Ca}$, $\mathrm{Mn}, \mathrm{Fe}, \mathrm{Co}, \mathrm{Ni}, \mathrm{Zn}$, and $\mathrm{Cd}$ ) were reported to be $3 \mathrm{D}$ solids in which $\mathrm{M}^{2+}$ ions were surrounded by six phosphonate groups to form eight-membered rings by alternating $\mathrm{MO}_{6}$ and $\mathrm{PO}_{3} \mathrm{C}$ polyhedra, with the layers connected by the organic groups. ${ }^{[19 \mathrm{a}-\mathrm{c}]}$

The fundamental topology and dimensionality of the four crystalline phosphonates 1-4 remains unchanged (Figure 2). However, the hydrogen-bonding network that holds the layers together undergoes profound changes with the swelling of the interlayer space due to the uptake/removal of guest species $\left(\mathrm{H}_{2} \mathrm{O}\right.$ and $\left.\mathrm{NH}_{3}\right)$. Structural analysis for compounds 1-4 indicates that, besides the apparent expanding of the interlayer space, the metal-organic layer undergoes conformational changes to accommodate the uptake/inclusion of the guest species. This breathing mechanism, swelling
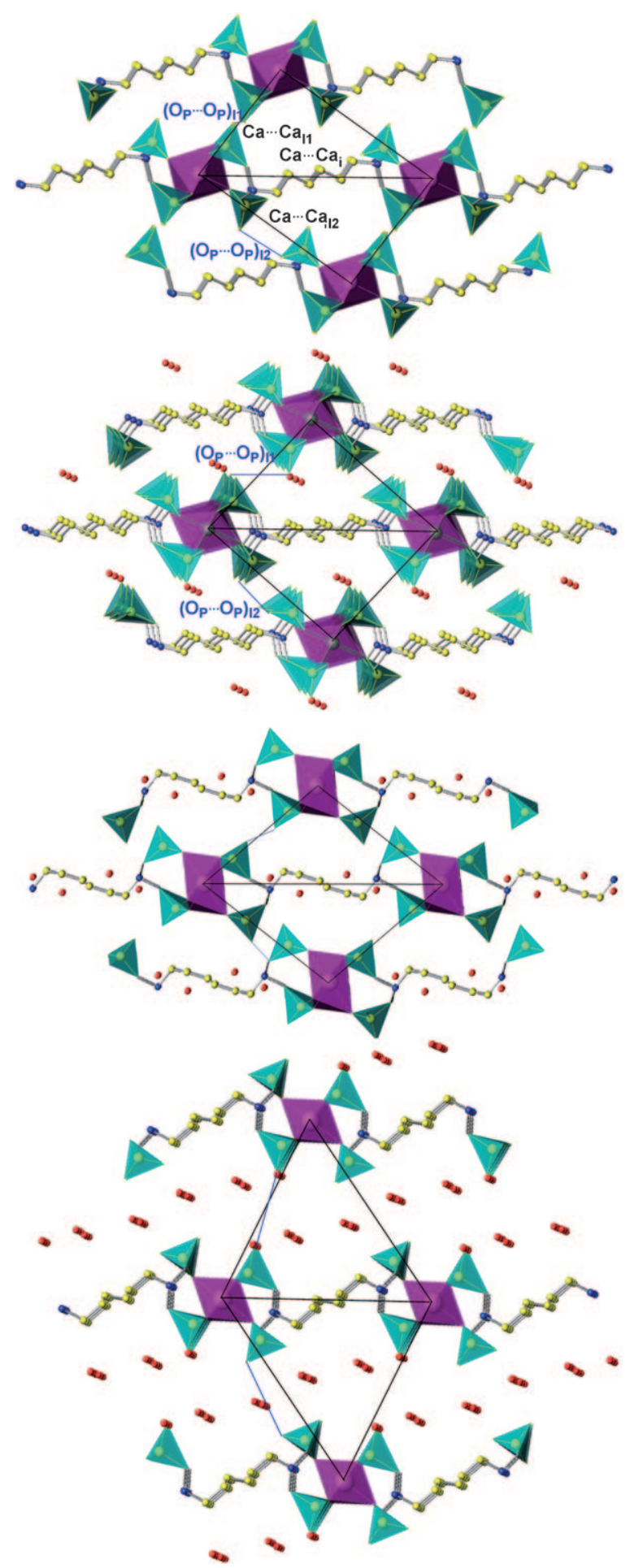

Figure 2. Structures of the hybrids illustrating the breathing with the uptake of guest species. From top to bottom: 2, 1, 4, and 3. Selected interatomic distances are highlighted and the values are given in Table 1.

plus subtle movement of the framework itself, has been previously reported for carboxylate-based metal-organic frameworks. $^{[26,27]}$

The anisotropic breathing motion can be quantified in three ways: $:^{[18]}$ a) by the changes in unit-cell dimensions, 


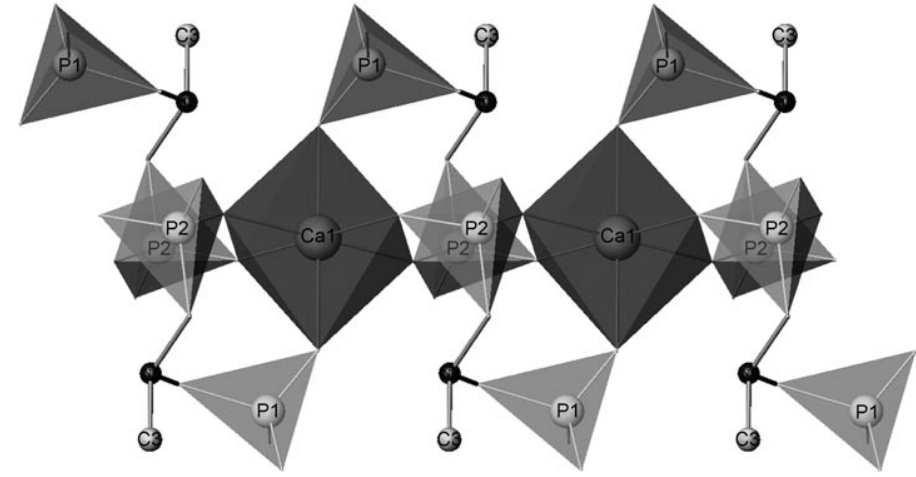

Figure 3. The structure of $\mathrm{CaH}_{6} \mathrm{DTMP} \cdot 2 \mathrm{H}_{2} \mathrm{O}$ (1) illustrating the $\mathrm{Ca} \cdots \mathrm{Ca}$ phosphonate bridges, which result in the formation infinite chains along the $a$ axis.

b) by the interactions between the guests and the layer framework, and c) by the structural alterations within the framework. First, the cell volume expands concomitantly with the breathing (Table 1) and an appropriate indicator is

Table 1. Key structural parameters for $\mathrm{CaH}_{6} \mathrm{DTMP}$ (2), $\mathrm{CaH}_{6} \mathrm{DTMP} \cdot 2 \mathrm{H}_{2} \mathrm{O} \quad$ (1), $\quad \mathrm{CaH}_{6} \mathrm{DTMP} \cdot 1.5 \mathrm{H}_{2} \mathrm{O} \cdot 1.5 \mathrm{NH}_{3} \quad$ (4), and $\mathrm{CaH}_{6} \mathrm{DTMP} \cdot 6 \mathrm{H}_{2} \mathrm{O} \cdot 4 \mathrm{NH}_{3}(\mathbf{3})$.

\begin{tabular}{lcrrr}
\hline & \multicolumn{1}{c}{$\mathbf{2}$} & \multicolumn{1}{c}{$\mathbf{1}$} & \multicolumn{1}{c}{$\mathbf{4}$} & \multicolumn{1}{c}{$\mathbf{3}$} \\
\hline$V_{\mathrm{op}} / V_{\mathrm{dry}}$ & \multicolumn{1}{c}{${ }$} & 1.13 & 1.21 & 1.55 \\
$\mathrm{Ca} \cdots \mathrm{Ca}_{a}[\AA]^{[\mathrm{a}]}$ & 5.79 & 5.73 & 5.79 & 5.82 \\
$\mathrm{Ca} \cdots \mathrm{Ca}_{l 1}[\AA]^{[\mathrm{b}]}$ & 8.18 & 9.59 & 10.36 & 11.84 \\
$\mathrm{Ca} \cdots \mathrm{Ca}_{l 2}[\AA]^{[\mathrm{c}]}$ & 11.54 & 11.02 & 11.12 & 12.86 \\
$\mathrm{Ca} \cdots \mathrm{Ca}_{i}[\AA]^{[\mathrm{d}]}$ & 14.30 & 18.05 & 17.57 & 17.10 \\
$\mathrm{~N} \cdots \mathrm{Ca}[\AA]^{[\mathrm{e}]}$ & 3.99 & 4.77 & 4.82 & 4.76 \\
$\mathrm{~N} \cdots \mathrm{N}[\AA]^{[\mathrm{f}]}$ & 8.93 & 8.81 & 7.99 & 7.94 \\
$\left(\mathrm{O}_{\mathrm{P}} \cdots \mathrm{O}_{\mathrm{P}}\right)_{l 1}[\AA]^{[\mathrm{g}]}$ & 2.82 & 4.26 & 3.08 & 4.82 \\
$\left(\mathrm{O}_{\mathrm{P}} \cdots \mathrm{O}_{\mathrm{P}}\right)_{l 2}[\AA]^{[\mathrm{g}]}$ & 3.04 & 2.52 & 3.10 & 4.75
\end{tabular}

[a] Shortest $\mathrm{Ca} \cdots \mathrm{Ca}_{a}$ intrainorganic chain distance (along the $\mathrm{CPO}_{3}$ bridges), which is the $a$ unit-cell parameter. [b] Shortest $\mathrm{Ca} \cdots \mathrm{Ca}_{l 1}$ interlayer distance. [c] Second shortest $\mathrm{Ca} \cdots \mathrm{Ca}_{12}$ interlayer distance. [d] Shortest $\mathrm{Ca} \cdots \mathrm{Ca}_{i}$ intraorganic chain distance (along the HDTMP ligand). [e] $\mathrm{N} \cdots \mathrm{Ca}$ distance along the eight-membered ring. [f] $\mathrm{N} \cdots \mathrm{N}$ distance along the organic chain. [g] Interlayer shortest distances ( $l 1$ and $l 2$ ) between the oxygen atoms of the phosphonate groups (Figure 2).

the $V_{\mathrm{op}} / V_{\mathrm{dry}}$ ratio ( $V_{\mathrm{op}}$ : cell volume of the open form, $V_{\mathrm{dry}}$ : cell volume of the anhydrous solid 2). The expansion is $55 \%$ for 3 , which is very large for hybrid materials, but not as impressive as that reported for MIL-88C (270\%, by using pyridine as a solvent in the synthetic process). ${ }^{[18]}$ The evolution of the unit-cell volume versus the number of guest molecules taken up is linear (Figure 4) with a slope of $26.9 \AA^{3}$ species $^{-1}$. Note that the volume occupied by a single water molecule in bulk liquid water is $29.9 \AA^{3}$ and that occupied by a single ammonia molecule in bulk liquid ammonia is $40.7 \AA^{3}$. Therefore, we must conclude that the packing of the guest $\mathrm{H}_{2} \mathrm{O} / \mathrm{NH}_{3}$ molecules in $\mathbf{3}$ is very compact.

Furthermore, the response of the framework towards incoming guest molecules can be rationalized by following the changes of the appropriate $\mathrm{Ca} \cdots \mathrm{Ca}$ interatomic distances. A

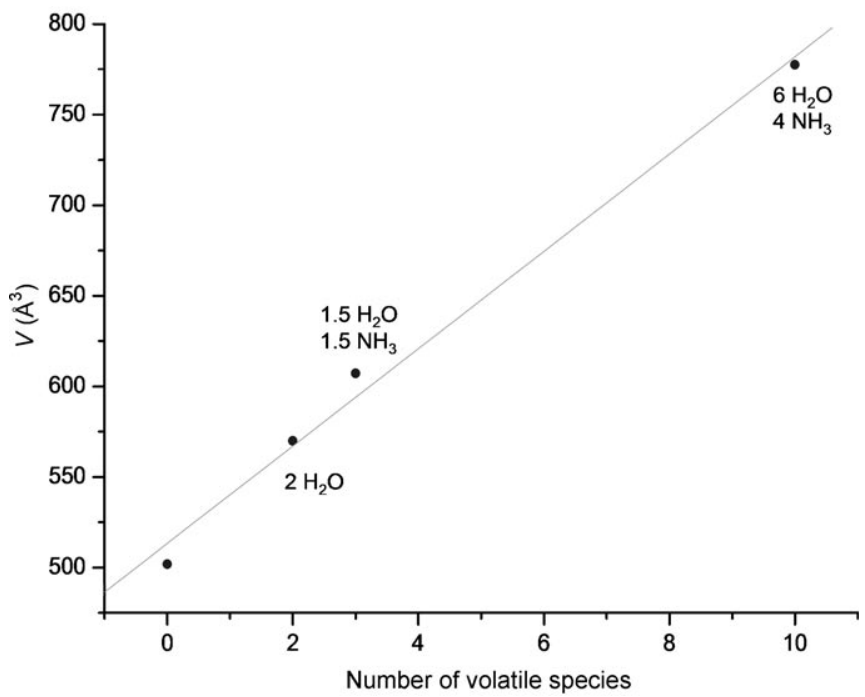

Figure 4. Unit-cell volumes of calcium tetraphosphonates as a function of the number of guest molecules $(y=26.872 x+513.306, R=0.9959)$.

noticeable feature of the reported expansion is the lack of variation of the $a$ parameter across the entire series from $\mathrm{Ca}$ to $\mathrm{Ca}_{a}$ (Table 1 ) because this distance is defined by the tetraphosphonate bridge (Figure 3). In addition, three other key $\mathrm{Ca} \cdots \mathrm{Ca}$ distances can be investigated (see Figure 2): $\mathrm{Ca} \cdots \mathrm{Ca}_{l 1}$ and $\mathrm{Ca} \cdots \mathrm{Ca}_{l 2}$ are the inequivalent interlayer distances, and $\mathrm{Ca} \cdots \mathrm{Ca}_{i}$ is the intralayer distance along the bridging organic ligand. The $\mathrm{Ca} \cdots \mathrm{Ca}_{l 1}$ distances (Table 1 ) smoothly increase along the series owing to the incorporation of the water molecules (see below). The $\mathrm{Ca} \cdots \mathrm{Ca}_{12}$ distances (Table 1) change at a much slower rate because the guest species are only incorporated between the phosphonate groups in $\mathbf{3}$.

In addition to the $\mathrm{Ca} \cdots \mathrm{Ca}_{i}$ distances (Figure 2, Table 1), it is also useful to examine the $\mathrm{N} \cdots \mathrm{N}$ distances across the ligand backbone as well as the $\mathrm{Ca} \cdots \mathrm{N}$ distances defined by the eight-membered chelate ring (Scheme 1 and Figure 2). As shown in Table 1 , the $\mathrm{Ca} \cdots \mathrm{N}$ distances generally remain quite constant in $\mathbf{1}, \mathbf{3}$, and $\mathbf{4}$ with values of approximately $4.8 \AA$. However, the $\mathrm{Ca} \cdots \mathrm{N}$ distance is much shorter in $\mathbf{2}$ at approximately $4.0 \AA$. The $\mathrm{N} \cdots \mathrm{N}$ distances within the phosphonate ligand decrease from approximately $8.8 \AA$ in the fully extended compounds $\mathbf{1}$ and $\mathbf{2}$ to approximately $8.0 \AA$ in the twisted compounds $\mathbf{3}$ and $\mathbf{4}$.

Finally, the origin of the framework motions described above is due to the incorporation/removal of guest species between the layers. Compound $\mathbf{2}$ is the anhydrous form and the layers interact by forming hydrogen bonds through the protonated phosphonate groups, mainly $\left(\mathrm{O}_{\mathrm{P}} \cdots \mathrm{O}_{\mathrm{P}}\right)_{l 1}$ and $\left(\mathrm{O}_{\mathrm{P}} \cdots \mathrm{O}_{\mathrm{P}}\right)_{l 2}$ (Figure 2 and Table 1$)$. These hydrogen-bonding $\mathrm{O} \cdots \mathrm{O}$ distances are 2.82 and $3.04 \AA$, respectively. The strong hydrogen-bonding interaction $\left(\mathrm{O}_{\mathrm{P}} \cdots \mathrm{O}_{\mathrm{P}}\right)_{l 1}$, which is absent in the other family members, is responsible for the rotation of the $-\mathrm{CPO}_{3}$ group with a concomitant shortening of the $\mathrm{Ca} \cdots \mathrm{N}$ distance described above. The incorporation of one $\mathrm{H}_{2} \mathrm{O}$ molecule between the layers in $\mathbf{1}$ results in an expan- 
sion of the $\left(\mathrm{O}_{\mathrm{P}} \cdots \mathrm{O}_{\mathrm{P}}\right)_{l 1}$ distance to $4.26 \AA$. Conversely, the $\left(\mathrm{O}_{\mathrm{P}} \cdots \mathrm{O}_{\mathrm{P}}\right)_{12}$ distance decreases. The oxygen of the water molecule interacts through hydrogen bonds formed with phosphonate moieties of the same layer with $\mathrm{O}_{\mathrm{P}} \cdots \mathrm{O}_{\mathrm{W}}$ distances of 2.66 and $2.65 \AA$. Note that in $\mathbf{1}$, the layers are held together by hydrogen bonds of the protonated phosphonate groups $-\mathrm{P}-\mathrm{OH},\left(\mathrm{O}_{\mathrm{P}} \cdots \mathrm{O}_{\mathrm{P}}\right)_{12}$ (Figure 2$)$. The $\mathrm{O}_{\mathrm{P}} \cdots \mathrm{O}_{\mathrm{P}}$ interatomic distances (Table 1) evolve in $\mathbf{3}$ and $\mathbf{4}$ owing to the presence of $\mathrm{H}_{2} \mathrm{O}$ and $\mathrm{NH}_{3}$ molecules. The distance $\left(\mathrm{O}_{\mathrm{P}} \cdots \mathrm{O}_{\mathrm{P}}\right)_{l 2}$ significantly increases only in $\mathbf{3}$ because the $\mathrm{H}_{2} \mathrm{O}$ / $\mathrm{NH}_{3}$ guest species are located between these protonated phosphonate groups (Figure 2).

Each adsorbate molecule is held between the layers by a large number of hydrogen bonds. For example, N2 in compound 3 has four close contacts that are $<3 \AA$. All four $\mathrm{N}$ atoms are close to phosphonate oxygen atoms at contacts in the range of $2.63-2.76 \AA$. These can be compared with $\mathrm{P}-\mathrm{O} \cdots \mathrm{H}-\mathrm{N}$ interactions in (en)(HDTMP). ${ }^{[23]}$

The nature of the $\mathrm{NH}_{3}$-framework interaction in $\mathbf{3}$ and $\mathbf{5}$ has been studied by temperature-programmed desorption of ammonia $\left(\mathrm{NH}_{3}-\mathrm{TPD}\right.$, Figure 5) and infrared spectroscopy. Compound $\mathbf{3}$ mainly releases $\mathrm{NH}_{3}$ in a single step centered at $100{ }^{\circ} \mathrm{C}$. The integration of this pattern gave $363.9 \mu \mathrm{mol}$ ( $8.6 \mathrm{wt} \%$ ) of $\mathrm{NH}_{3}$. This behavior is in agreement with the thermogravimetric analysis (TGA) curve (Figure 6) in which the main weight loss is located just below $100^{\circ} \mathrm{C}$. However, compound 5 releases $\mathrm{NH}_{3}$ in two distinct steps centered at 90 and $230^{\circ} \mathrm{C}$. The integration of this pattern gave 572.8 $\mu \mathrm{mol}(12.3 \mathrm{wt} \%)$ of $\mathrm{NH}_{3}$. This behavior is also in full agreement with the TGA curve (Figure 6) in which two weight losses are observed at these temperatures. The absence of water of crystallization in $\mathbf{5}$ indicates a much stronger hydrogen-bonding interaction of some $\mathrm{NH}_{3}$ guest molecules with the framework. Approximately two $\mathrm{NH}_{3}$ molecules per structural formula unit are released close to $230^{\circ} \mathrm{C}$.

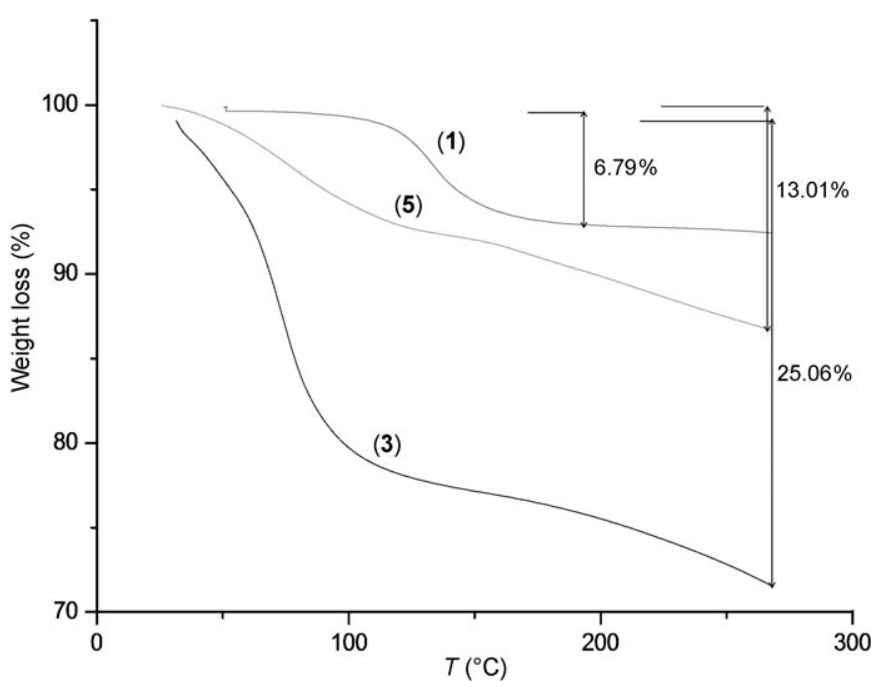

Figure 6. Thermogravimetric traces of $\mathrm{CaH}_{6} \mathrm{DTMP} \cdot 2 \mathrm{H}_{2} \mathrm{O}$ (1), $\mathrm{CaH}_{6} \mathrm{DTMP} \cdot 6 \mathrm{H}_{2} \mathrm{O} \cdot 4 \mathrm{NH}_{3}(\mathbf{3})$, and $\mathrm{CaH}_{6} \mathrm{DTMP} \cdot 5 \mathrm{NH}_{3}(\mathbf{5})$.

Infrared spectra for $\mathbf{1}, \mathbf{2}, \mathbf{3}$, and $\mathbf{5}$ are given in Figure 7. These spectra show bands similar to other $\mathrm{M}^{\mathrm{II}} \mathrm{H}_{6} \mathrm{DTMP}$ materials. ${ }^{[25]}$ Two bands centered at 3575 and $1665 \mathrm{~cm}^{-1}$ have been selected to clarify the nature of the $\mathrm{NH}_{3}$ interactions. The $\mathrm{H}-\mathrm{N}-\mathrm{H}$ bending vibration band for $\mathbf{5}$ centered at $1680 \mathrm{~cm}^{-1}$ can be assigned to ammonia species adsorbed on to different $-\mathrm{PO}_{3} \mathrm{H}^{-}$Brønsted acid sites. Heating of 5 (and 3) induces $\mathrm{NH}_{3}$ release and the protons remain with the $\mathrm{PO}_{3}{ }^{2-}$ groups. Intercalation of alkylamines or alkyldiamines in layered metal phosphonates (e.g., $\mathrm{Zr}$-carboxyethylphosphonate, ${ }^{[28 \mathrm{a}]} \mathrm{Zr}$-phosphonomethyliminodiacetate, ${ }^{[28 \mathrm{~b}]}$ and vanadyl monophosphonates ${ }^{[28 c]}$ ) has also been reported to be accompanied by Brønsted acid/base behavior.

Finally, efforts to intercalate larger amines ( $n$-propylamine and ethylendiamine) or alcohols (ethanol and $n$-pentanol) into $\mathbf{1}$ or $\mathbf{2}$ were unsuccessful.

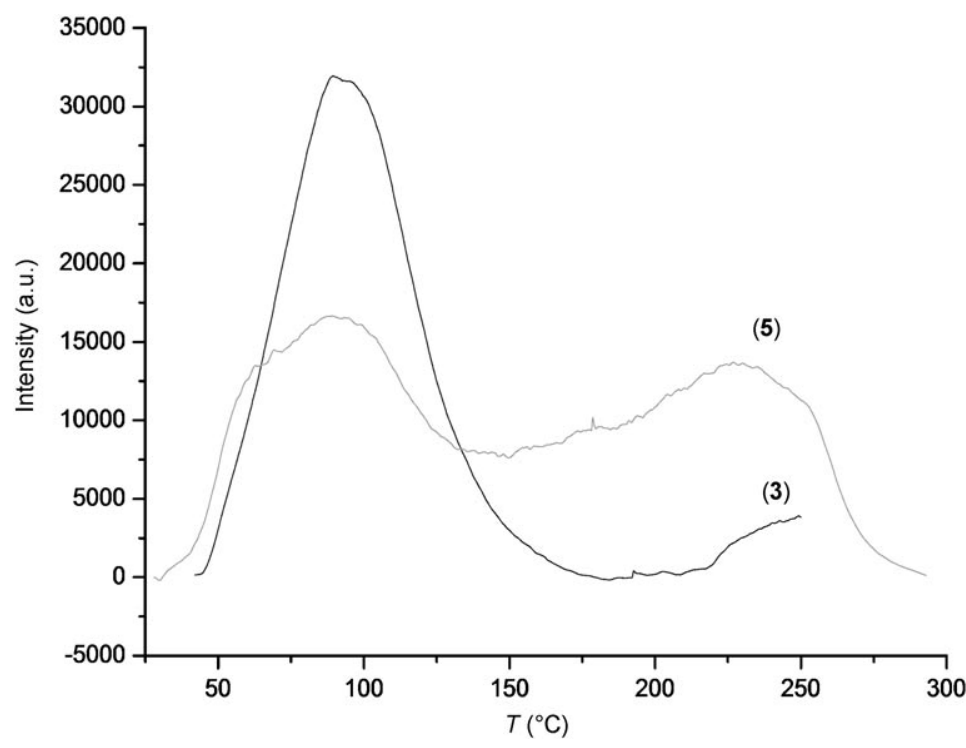

Figure 5. Thermoprogrammed ammonia desorption curves for $\mathbf{3}$ and $\mathbf{5}$.

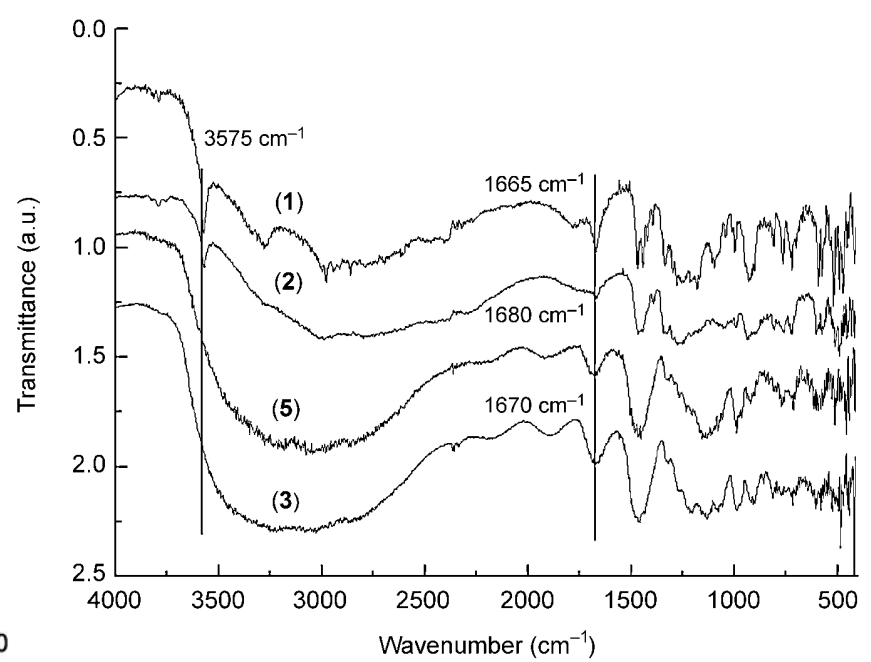

Figure 7. FTIR spectra for $\mathrm{CaH}_{6} \mathrm{DTMP} \cdot 2 \mathrm{H}_{2} \mathrm{O}$ (1), $\mathrm{CaH}_{6} \mathrm{DTMP}$ (2), $\mathrm{CaH}_{6} \mathrm{DTMP} \cdot 5 \mathrm{NH}_{3}(\mathbf{5})$, and $\mathrm{CaH}_{6} \mathrm{DTMP} \cdot 6 \mathrm{H}_{2} \mathrm{O} \cdot 4 \mathrm{NH}_{3}$ (3). 


\section{Conclusion}

The reversible breathing mechanism, already reported for metal-carboxylate MOFs, has been extended to layered metal-phosphonate hybrids. The crystal structures of calcium tetraphosphonates undergo a swelling upon $\mathrm{NH}_{3} / \mathrm{H}_{2} \mathrm{O}$ uptake with a concomitant twisting of the organic ligand, which allows a compact arrangement of the guest molecules. Furthermore, the storage of pure $\mathrm{NH}_{3}(12.3 \mathrm{wt} \%)$ is also reported. To the best of our knowledge, these are the first structurally characterized examples of $2 \mathrm{D}$ materials that can reversibly store and remove host molecules while the framework adjusts to these external stimuli by subtle changes within the framework. Proof that subtle motion within the framework to accommodate the large number of host molecules (from 0 to 10 ) reveals that this breathing framework is highly responsive to the presence of adsorbates.

\section{Experimental Section}

General: All starting materials were obtained from commercial sources. Elemental analyses $(\mathrm{C}, \mathrm{H}, \mathrm{N})$ were measured on a Perkin-Elmer 240 analyzer. TGA data were recorded on an SDT-Q600 analyzer from TA instruments. The temperature varied from RT to $300^{\circ} \mathrm{C}$ at a heating rate of $10^{\circ} \mathrm{Cmin}^{-1}$. Measurements were carried out on samples in open platinum crucibles under a flow of air

$\mathbf{C a P}_{4} \mathbf{O}_{12} \mathbf{N}_{2} \mathbf{C}_{10} \mathbf{H}_{26} \cdot \mathbf{2} \mathbf{H}_{2} \mathbf{O}$ (1): Solid HDTMP (0.984 g, $\left.2.00 \mathrm{mmol}\right)$ was suspended in deionized water $(80 \mathrm{~mL})$. A stock solution of $\mathrm{NH}_{3}(1 \mathrm{M})$ was added dropwise until the $\mathrm{pH}$ reached $\sim 2.5$, at which point the solid HDTMP dissolved. Solid $\mathrm{CaCl}_{2} \cdot 2 \mathrm{H}_{2} \mathrm{O}(0.29 \mathrm{~g}, 2.00 \mathrm{mmol})$ was added to the stirred solution. The final $\mathrm{pH}$ was adjusted to 2.5 and the clear colorless solution was left to stand. After 2-3 days a microcrystalline product formed, which was isolated by filtration, washed with deionized water, and air dried to yield a single-phase product (yield $\sim 65 \%$ ). Higher yields of up to $80 \%$ were obtained by prolonged crystallization, or when the filtrate was allowed to precipitate more product for four additional days. Elemental analysis calcd (\%) for $\mathrm{CaP}_{4} \mathrm{O}_{14} \mathrm{~N}_{2} \mathrm{C}_{10} \mathrm{H}_{30}$ : C 21.21, H 5.34, N 4.95; found: $\mathrm{C} 20.92, \mathrm{H} 4.98, \mathrm{~N} 5.16$; TGA (weight loss up to $250^{\circ} \mathrm{C}$ ) calcd (\%) for $2 \mathrm{H}_{2} \mathrm{O}: 6.3$; found: 6.8 .

$\mathrm{CaP}_{4} \mathbf{O}_{12} \mathbf{N}_{2} \mathbf{C}_{10} \mathbf{H}_{26}$ (2): Compound 2 was obtained upon dehydration of $\mathbf{1}$ at $250{ }^{\circ} \mathrm{C}$. Elemental analysis calcd $(\%)$ for $\mathrm{CaP}_{4} \mathrm{O}_{12} \mathrm{~N}_{2} \mathrm{C}_{10} \mathrm{H}_{26}: \mathrm{C} 22.65, \mathrm{H}$ 4.94, N 5.28; found: C 22.02, H 5.18, N 4.98 .

\section{Absorption of $\mathrm{NH}_{3}$ vapors (aqueous solution):}

$\mathrm{CaP}_{4} \mathrm{O}_{12} \mathrm{~N}_{2} \mathrm{C}_{10} \mathrm{H}_{26} \cdot 6 \mathrm{H}_{2} \mathrm{O} \cdot 4 \mathrm{NH}_{3}(\mathbf{3})$ : Compound $\mathbf{1}$ or $\mathbf{2}(150 \mathrm{mg})$ was placed in contact with vapors from a commercial aqueous solution of $\mathrm{NH}_{3}(28$ $\mathrm{wt} \%)$. Full reaction took place after $4 \mathrm{~h}$ in a closed vessel. The product was air dried for $30 \mathrm{~min}$ to yield solid $\mathbf{3}$. Elemental analysis calcd (\%) for $\mathrm{CaP}_{4} \mathrm{O}_{18} \mathrm{~N}_{6} \mathrm{C}_{10} \mathrm{H}_{50}$ : C 17.00, H 7.23, N 11.90; found: C 16.19, H 7.98, N 10.88; TGA (weight loss up to $250^{\circ} \mathrm{C}$ ) calcd (\%) for $\mathbf{3}$ with a loss of $6 \mathrm{H}_{2} \mathrm{O}$ and $4 \mathrm{NH}_{3}: 24.94$; found: 25.06 .

$\mathrm{CaP}_{4} \mathrm{O}_{12} \mathrm{~N}_{2} \mathrm{C}_{10} \mathrm{H}_{26} \cdot 1.5 \mathrm{H}_{2} \mathrm{O} \cdot 1.5 \mathrm{NH}_{3}(4)$ : Compound 3 transforms into the new crystalline phase $\mathbf{4}$ upon heating at $90^{\circ} \mathrm{C}$. The stoichiometry of $\mathbf{4}$ was deduced from the elemental analysis and the thermal study. Elemental analysis calcd (\%) for $\mathrm{CaP}_{4} \mathrm{O}_{13.5} \mathrm{~N}_{3.5} \mathrm{C}_{10} \mathrm{H}_{30.5}$ : C 20.60, H 5.79, N 8.41; found: C 21.44, H 5.29, N 8.48.

Absorption of pure $\mathbf{N H}_{3}$ (gas): $\mathrm{CaP}_{4} \mathrm{O}_{12} \mathbf{N}_{2} \mathrm{C}_{10} \mathrm{H}_{26} \cdot \mathbf{S N H}_{3}(5)$ : Compound 2 $(100 \mathrm{mg})$ was placed in a tube and heated at $250^{\circ} \mathrm{C}$ for $30 \mathrm{~min}$ under $\mathrm{He}$ flux. The solid was then treated with a pure $\mathrm{NH}_{3}$ flow at $30^{\circ} \mathrm{C}$ for $95 \mathrm{~min}$. The ammonia content was determined from the programmed desorption up to $250^{\circ} \mathrm{C}$ and also from the thermal study, which yielded the approximate stoichiometry $\mathrm{CaP}_{4} \mathrm{O}_{12} \mathrm{~N}_{2} \mathrm{C}_{10} \mathrm{H}_{26} \cdot 5 \mathrm{NH}_{3}$. TGA (weight loss up to $250^{\circ} \mathrm{C}$ ) calcd (\%) for $\mathrm{CaP}_{4} \mathrm{O}_{12} \mathrm{~N}_{7} \mathrm{C}_{10} \mathrm{H}_{41}: 13.82$; found: 13.01 .
Temperature-programmed desorption of ammonia $\left(\mathbf{N H}_{3}\right.$-TPD): These measurements were carried out to evaluate the acid properties of $\mathbf{3}$ and 5. First, the samples were treated with helium from RT to $250^{\circ} \mathrm{C}$ with a heating rate of $10^{\circ} \mathrm{C} \mathrm{min}^{-1}$. After the adsorption of ammonia at RT and cleaning with helium, the $\mathrm{NH}_{3}$-TPD was performed between RT and $250^{\circ} \mathrm{C}$ with a heating rate of $7^{\circ} \mathrm{C} \mathrm{min}{ }^{-1}$ by using a helium flow and was maintained at $250^{\circ} \mathrm{C}$ for $10 \mathrm{~min}$. The evolved ammonia was monitored by online gas chromatography with a Shimadzu GC-14 A apparatus equipped with a thermal conductivity detector.

Infrared spectroscopy: DRIFT spectra were collected on a Harrick HVC-DRP cell fitted to a Varian 3100 FTIR spectrophotometer. The interferograms consisted of 120 scans and the spectra were collected by using a $\mathrm{KBr}$ spectrum as the background. Approximately $30 \mathrm{mg}$ of the finely ground sample was placed in a sample holder and the spectra were recorded between 400 and $4000 \mathrm{~cm}^{-1}$.

Powder X-ray diffraction data: Laboratory powder XRD data were collected on a PANanalytical X'Pert Pro automated diffractometer. The powder XRD patterns for $\mathbf{1}$ and $\mathbf{2}$ (flat sample) were recorded in the Bragg-Brentano reflection configuration by using a Ge(111) primary monochromator $\left(\mathrm{Cu}_{\mathrm{Kal}}\right)$ and the $\mathrm{X}^{\prime}$ Celerator detector. The powder XRD patterns were recorded between 5 and $100^{\circ} \mathrm{C}$ in $2 \theta$ mode with a step size of $0.017^{\circ}$ and an equivalent counting time of $712 \mathrm{~s}$ per step. The powder XRD pattern of $\mathbf{2}$ was collected by heating $\mathbf{1}$ in situ under vacuum $(\sim 0.01$ bar $)$ at $5^{\circ} \mathrm{Cmin}^{-1}$ up to $250^{\circ} \mathrm{C}$. After $10 \mathrm{~min}$, the temperature was dropped to $30^{\circ} \mathrm{C}$ and immediately a new set of data was collected as described above. No extra signals corresponding to $\mathbf{1}$ were observed. The powder XRD pattern for $\mathbf{3}$ (sample was placed within a sealed $0.5 \mathrm{~mm}$ borosilicate glass capillary) was recorded in the Debye-Scherrer transmission configuration by using a hybrid $\mathrm{Ge}(220)$ primary monochromator $\left(\mathrm{Cu}_{\mathrm{Ka1}}\right)$ and the $\mathrm{X}^{\prime}$ Celerator detector. The powder XRD pattern was recorded between 4 and $90^{\circ}$ in $2 \theta$ mode with a step size of $0.017^{\circ}$ and an equivalent counting time of $1000 \mathrm{~s}$ per step. Powder XRD data for 4 were recorded in reflection mode by heating 3 in situ under a continuous flux of $\mathrm{He}$ at $5^{\circ} \mathrm{Cmin}^{-1}$ up to $90^{\circ} \mathrm{C}$. After $10 \mathrm{~min}$ at $90^{\circ} \mathrm{C}$, data were collected between 4 and $100^{\circ}(2 \theta)$ with a step size of $0.017^{\circ}$ and an equivalent counting time of $610 \mathrm{~s}$ per step. The thermodiffractometric studies of 1 and 2 were carried out by using an Anton Paar TTK450 camera under vacuum. The thermodiffractometric study of $\mathbf{3}$ was carried out by using an Anton Paar HTK $1200 \mathrm{~N}$ camera with a continuous flux $\left(0.02 \mathrm{~L} \mathrm{~min}^{-1}\right)$ of $\mathrm{He}$ as an inert gas. Data were collected at small intervals $\left(10^{\circ} \mathrm{C}\right)$ from $-170^{\circ} \mathrm{C}$ up to $250^{\circ} \mathrm{C}$ with a delay time of $10 \mathrm{~min}$. The data range was 4 $50^{\circ}(2 \theta)$ with a step size of $0.017^{\circ}$.

Structure determination: Powder XRD patterns corresponding to the single phases were autoindexed as triclinic cells by using the DICVOL06 program $^{[29]}$ with the space group $P \overline{1}$ and $Z=1$. The crystal structure of $\mathbf{1}$ was solved by following an ab initio methodology. The pattern decomposition option of the GSAS package ${ }^{[30]}$ was used to extract structure factors by using the Le Bail method. ${ }^{[31]}$ Structure determination by direct methods was carried out by using the program Sir2004 ${ }^{[32]}$ in the default settings, which gave all atoms present in the asymmetric unit. The crystal structures of $\mathbf{2}, \mathbf{3}$, and $\mathbf{4}$ were determined by using the crystal structure of $\mathbf{1}$ as the initial model. The missing atoms were localized by difference Fourier maps. For compounds $\mathbf{3}$ and $\mathbf{4}$, the water and ammonia molecules were included as oxygen atoms because they cannot be distinguished by powder XRD. There are no signatures of water/ammonia ordering in the powder XRD patterns. The crystal structures were refined by the Rietveld method ${ }^{[33]}$ with the GSAS package ${ }^{[30]}$ and by using soft constraints in accordance with chemically reasonable geometries for the phosphonate and amine groups and the alkyl chains. The soft constraints for the $\mathrm{PO}_{3} \mathrm{C}$ tetrahedron were $\mathrm{P}-\mathrm{O}(1.53(1) \AA), \mathrm{P}-\mathrm{C}(1.80(1) \AA), \mathrm{O} \cdots \mathrm{O}(2.55(2) \AA)$, and $\mathrm{O} \cdots \mathrm{C}(2.73(2) \AA)$; for the $\mathrm{N}\left(\mathrm{CH}_{2}\right)_{3}$ amine group $\mathrm{N}-\mathrm{C}(1.50(1) \AA)$,

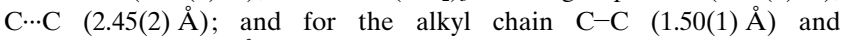
$\mathrm{C}_{\text {chain }} \cdots \mathrm{C}_{\text {chain }}(2.50(2) \AA)$. Hydrogen atoms were not included in the refinements. The final Rietveld plots are given in the Supporting Information. Refinement details: $\mathrm{CaP}_{4} \mathrm{O}_{12} \mathrm{~N}_{2} \mathrm{C}_{10} \mathrm{H}_{26} \cdot 2 \mathrm{H}_{2} \mathrm{O}$ (1): $M=566.09 \mathrm{~g} \mathrm{~mol}^{-1} ; a=$ 5.72775(13) $, \quad b=9.58755(20), \quad c=11.02041(23) \AA ; \quad \alpha=90.0839(10), \quad \beta=$ 105.0761(14), $\quad \gamma=102.2051(10)^{\circ} ; \quad V=570.13(3) \AA^{3} ; \quad \rho_{\text {calcd }}=1.561 \mathrm{~g} \mathrm{~cm}^{-3}$; total reflections 691 ; number of parameters 114 ; number of restraints 32 ; 
w $R_{\mathrm{p}}=0.0787 ; \quad R_{\mathrm{p}}=0.0607 ; \quad R_{\mathrm{F}}=0.042 . \quad \mathrm{CaP}_{4} \mathrm{O}_{12} \mathrm{~N}_{2} \mathrm{C}_{10} \mathrm{H}_{26} \quad(\mathbf{2}): \quad M=$ $530.09 \mathrm{~g} \mathrm{~mol}^{-1} ; \quad a=5.7908(6), \quad b=8.1761(9), \quad c=11.5388(11) \AA ; \quad \alpha=$ 99.658(6), $\quad \beta=76.598(8), \quad \gamma=108.294(4)^{\circ} ; \quad V=501.90(12) \AA^{3} ; \quad \rho_{\text {calcd }}=$ $1.667 \mathrm{~g} \mathrm{~cm}^{-3}$; total reflections 549 ; number of parameters 74 ; number of restraints $\quad 34 ; \quad \mathrm{w} R_{\mathrm{p}}=0.1627 ; \quad R_{\mathrm{p}}=0.1231 ; \quad R_{\mathrm{F}}=0.086 . \quad$ Ca$\mathrm{P}_{4} \mathrm{O}_{12} \mathrm{~N}_{2} \mathrm{C}_{10} \mathrm{H}_{26} \cdot 6 \mathrm{H}_{2} \mathrm{O} \cdot 4 \mathrm{NH}_{3}(3): M=704.08 \mathrm{~g} \mathrm{~mol}^{-1} ; a=5.8157(4), \quad b=$ 11.8428 (11), $c=12.8644(10) ; \alpha=62.693(4), \beta=83.667(5), \gamma=81.256(4)^{\circ}$; $V=777.30(13) \AA^{3} ; \rho_{\text {calcd }}=1.419 \mathrm{~g} \mathrm{~cm}^{-3}$; total reflections 926 ; number of parameters 109; number of restraints $37 ; \mathrm{w} R_{\mathrm{p}}=0.0780 ; R_{\mathrm{p}}=0.0608 ; R_{\mathrm{F}}=$ 0.052. $\mathrm{CaP}_{4} \mathrm{O}_{12} \mathrm{~N}_{2} \mathrm{C}_{10} \mathrm{H}_{26} \cdot 1.5 \mathrm{H}_{2} \mathrm{O} \cdot 1.5 \mathrm{NH}_{3}$ (4): $\quad M=582.86 \mathrm{~g} \mathrm{~mol}^{-1} ; \quad a=$ 5.7897(9), $b=10.358(2), c=11.119(1) \AA ; \alpha=99.824(8), \beta=104.92(1), \gamma=$ $103.543(8)^{\circ} ; V=607.18(19) \AA^{3} ; \rho_{\text {calcd }}=1.510 \mathrm{~g} \mathrm{~cm}^{-3}$; total reflections 343 ; number of parameters 109 ; number of restraints $46 ; \mathrm{w} R_{\mathrm{p}}=0.1205 ; R_{\mathrm{p}}=$ $0.0854 ; R_{\mathrm{F}}=0.0468$. CCDC-660515 (1), 660514 (2), $707272(\mathbf{3})$, and 704225 (4) contains the supplementary crystallographic data for this paper. These data can be obtained free of charge from The Cambridge Crystallographic Data Centre via www.ccdc.cam.ac.uk/data_request/cif.

\section{Acknowledgements}

The work at UMA was funded by MICINN through research grant MAT2006-11080-C02-01. The work at UOC was funded by the Special Research Account (ELKE), project KA 2573.

[1] a) S. Bauer, N. Stock, Angew. Chem. 2007, 119, 6981-6984; Angew. Chem. Int. Ed. 2007, 46, 6857-6860; b) N. Stock, T. Bein, Angew. Chem. 2004, 116, 767-770; Angew. Chem. Int. Ed. 2004, 43, 749752.

[2] a) F. Bonino, S. Chavan, J. G. Vitillo, E. Groppo, G. Agostini, C. Lamberti, P. D. C. Dietzel, C. Prestipino, S. Bordiga, Chem. Mater. 2008, 20, 4957-4968; b) S. Horike, R. Matsuda, D. Tanaka, S. Matsubara, M. Mizuno, K. Endo, S. Kitagawa, Angew. Chem. 2006, 118, 7384; Angew. Chem. Int. Ed. 2006, 45, 7226-7230; c) C. MellotDraznieks, C. Serre, S. Surble, N. Audebrand, G. Férey, J. Am. Chem. Soc. 2005, 127, 16273-16278.

[3] a) U. Mueller, M. Schubert, F. Teich, H. Puetter, K. Schierle-Arndt, J. Pastre, J. Mater. Chem. 2006, 16, 626-636; b) G. B. Hix, V. C. Maddocks, K. D. M. Harris, Polyhedron 2000, 19, 765-770.

[4] 1st International Conference on Metal-Organic Frameworks and Open-Framework Compounds, Augsburg (Germany), 2008.

[5] a) O. M. Yaghi, Nat. Mater. 2007, 6, $92-93$; b) J. T. Hupp, K. R. Poeppelmeier, Science 2005, 309, 2008-2009.

[6] a) A. Popa, C.-M. Davidescu, P. Negrea, G. Ilia, A. Katsaros, K. D. Demadis, Ind. Eng. Chem. Res. 2008, 47, 2010-2017; b) T.-Y. Ma, X.-J. Zhang, G.-S. Shao, J.-L. Cao, Z.-Y. Yuan, J. Phys. Chem. C 2008, 112, 3090-3096.

[7] G. Alberti, M. Casciola, Solid State Ionics 2001, 145, 3-16.

[8] a) A. G. Wong-Foy, A. J. Matzger, O. M. Yaghi, J. Am. Chem. Soc. 2006, 128, 3494-3495; b) J. L. C. Rowsell, A. R. Millward, K. S. Park, O. M. Yaghi, J. Am. Chem. Soc. 2004, 126, 5666-5667; c) M. Latroche, S. Surblé, C. Serre, C. Mellot-Draznieks, P. L. Llewellyn, J.-H. Lee, J.-S. Chang, S. H. Jhung, G. Férey, Angew. Chem. 2006, 118, 8407-8411; Angew. Chem. Int. Ed. 2006, 45, 8227-8231; d) X. Zhao, B. Xiao, A. J. Fletcher, K. M. Thomas, D. Bradshaw, M. J. Rosseinsky, Science 2004, 306, 1012-1015.

[9] C. Serre, S. Bourrelly, A. Vimont, N. A. Ramsahye, G. Maurin, P. L. Llewellyn, M. Daturi, Y. Filinchuk, O. Leynaud, P. Barnes, G. Férey, Adv. Mater. 2007, 19, 2246-2251.

[10] a) N. Rosenbach, Jr., H. Jobic, A. Ghoufi, F. Salles, G. Maurin, S. Bourrelly, P. L. Llewellyn, T. Devic, C. Serre, G. Férey, Angew. Chem. 2008, 120, 6713-6717; Angew. Chem. Int. Ed. 2008, 47, 66116615 ; b) P. L. Llewellyn, S. Bourrelly, C. Serre, A. Vimont, M.
Daturi, L. Hamon, G. De Weireld, J.-S. Chang, D.-Y. Hong, Y. K Hwang, S. H. Jhung, G. Férey, Langmuir 2008, 24, 7245-7250.

[11] a) P. Trens, N. Tanchoux, C. Serre, T. Loiseau, F. Millange, G. Férey, F. Fajula in Studies in Surface Science and Catalysis, Vol. 170 (Eds. R. Xu, J. Chen, Z. Guo, W. Yan), Elsevier, Amsterdam, 2007, pp. 855-860; b) S. H. Jhung, J.-H. Lee, J. W. Yoon, C. Serre, G. Férey, J.-S. Chang, Adv. Mater. 2007, 19, 121-124.

[12] a) U. Ravon, M. E. Domine, C. Gaudille're, A. Desmartin-Chomel, D. Farrusseng, New J. Chem. 2008, 32, 937-940; b) S. Opelt, S. Türk, E. Dietzsch, A. Henschel, S. Kaskel, E. Klemm, Catal. Commun. 2008, 9, 1286-1290.

[13] B. D. Chandler, G. D. Enright, K. A. Udachin, S. Pawsey, J. A. Ripmeester, D. T. Cramb, G. K. H. Shimizu, Nat. Mater. 2008, 7, 229 235.

[14] C. Scherb, A. Schödel, T. Bein, Angew. Chem. 2008, 120, 58615863; Angew. Chem. Int. Ed. 2008, 47, 5777-5779.

[15] W. Kaneko, M. Mito, S. Kitagawa, M. Ohba, Chem. Eur. J. 2008, 14 , 3481-3489.

[16] a) T. K. Maji, R. Matsuda, S. Kitagawa, Nat. Mater. 2007, 6, $142-$ 148; b) V. Finsy, H. Verelst, L. Alaerts, D. De Vos, P. A. Jacobs, G. V. Baron, J. F. M. Denayer, J. Am. Chem. Soc. 2008, 130, 71107118.

[17] a) G. Férey, Chem. Soc. Rev. 2008, 37, 191-214; b) G. Férey, C. Mellot-Draznieks, C. Serre, F. Millange, J. Dutour, S. Surble, I. Margiolaki, Science 2005, 309, 2040-2042.

[18] C. Serre, C. Mellot-Draznieks, S. Surblé, N. Audebrand, Y. Filinchuk, G. Férey, Science 2007, 315, 1828-1831.

[19] a) N. Stock, A. Stoll, T. Bein, Microporous Mesoporous Mater. 2004 $69,65-69 ;$ b) N. Stock, M. Rauscher, T. Bein, J. Solid State Chem. 2004, 177, 642-647; c) N. Stock, T. Bein, Angew. Chem. 2004, 116 , 767-770; Angew. Chem. Int. Ed. 2004, 43 749-752; d) P. Kaempfe, N. Stock, Z. Anorg. Allg. Chem. 2008, 634, 714-717.

[20] F. Constantino, T. Bataille, N. Audebrand, E. Le Fur, C. Sangregorio, Cryst. Growth Des. 2007, 7, 1881-1888.

[21] R. Vivani, F. Constantino, U. Constantino, M. Nocchetti, Inorg. Chem. 2006, 45, 2388.

[22] A. Clearfield, Prog. Inorg. Chem. 1997, 47, 371-510.

[23] a) K. D. Demadis, E. Barouda, R. G. Raptis, Z. Hong, Inorg. Chem. 2009, 48, 819-821; b) E. Barouda, K. D. Demadis, S. R. Freeman, F Jones, M. I. Ogden, Cryst. Growth Des. 2007, 7, 321-327.

[24] G.-L. Zheng, J.-F. Ma, J. Yang, J. Chem. Res. 2004, 387-388.

[25] K. D. Demadis, C. Mantzaridis, R. G. Raptis, G. Mezei, Inorg Chem. 2005, 44, 4469-4471.

[26] K. Barthelet, J. Marrot, D. Riou, G. Férey, Angew. Chem. 2002, 114, 291-294; Angew. Chem. Int. Ed. 2002, 41, 281-284.

[27] S. Kitagawa, K. Uemura, Chem. Soc. Rev. 2005, 34, 109-119, and references therein.

[28] a) T. Kijima, S. Watanabe, M. Machida, Inorg. Chem. 1994, 33, 2586-2591; b) B. Zhang, D. M. Poojary, A. Clearfield, G. Peng, Chem. Mater. 1996, 8, 1333-1340; c) P. Gendraud, M. E. de Roy, J. P. Besse, Inorg. Chem. 1996, 35, 6108-6112.

[29] A. Boultif, D. Louer, J. Appl. Crystallogr. 2004, 37, 724-731.

[30] a) B. H. Toby, J. Appl. Crystallogr. 2001, 34, 210-221; b) A. C. Larson, R. B. von Dreele, Los Alamos National Lab. Rep. No. LAUR-86-748, 2000.

[31] A. Le Bail, H. Duroy, J. L. Fourquet, Mater. Res. Bull. 1988, 23 , 447-452.

[32] M. C. Burla, M. Camall, B. Carrozzini, G. L. Cascarano, C. Giacovazzo, G. Polidori, R. Spagna, J. Appl. Crystallogr. 2003, 36, $1103-$ 1104.

[33] H. M. Rietveld, J. Appl. Crystallogr. 1969, 2, 65-71.

Received: March 2, 2009 Published online: May 28, 2009 
